\title{
Evaluation and Prevention of Changes in Oral Cavity Through Cytotoxic Effect of the Chemical Components from Dental Materials
}

\author{
ADINA OANA ARMENCIA ${ }^{1}$, CATALINA IULIA SAVEANU ${ }^{1 *}$, LOREDANA LILIANA HURJ UI ${ }^{1}$, ADRIAN DORIN CHERCI ${ }^{1}$, \\ CARINA BALCOS ${ }^{1}$, RUXANDRA NICOLETTE VOINEA GEORGESCU², CRISTINA CLAUDIA TARNICERIU', \\ DANIELA ANISTOROAEI ${ }^{1}$ \\ 'University of Medicine and Pharmacy Grigore T. Popa, Faculty of Dental Medicine, Department of Surgery, 16, Universitatii Str., \\ 700115, Iasi, Romania \\ 2Universitatea Titu Maiorescu, Faculty of Dental Medicine Priodontology,67A Gh. Petrascu Str., 031593, Bucharest, Romania
}

\begin{abstract}
The use of a suitable biological material, represented by the normal cell culture cell line RM, consisting of monkey kidney cells or of suitable experimental models allow the investigation of the reactivity of the cell protein synthesis process (illustrated by the total protein content of the cell cultures aged 72 hours, after a 48-hour treatment), cell proliferation (expressed by the evolution of the total cell number during cell culture development), cell viability (characterized by the dynamics of the dead/living cells ratio), cell apoptosis and cell culture development. Alteration of these processes reflects the cytotoxic impact of some products on protein synthesis, mitosis, cell apoptosis and cell viability.
\end{abstract}

Keywords: protein synthesis, flowcitometry, dental materials

In vitro research, on cell systems of human or animal origin, offers the possibility of direct monitoring of the cytotoxic effects that occur as a result of the direct contact between the drug and the target cells, providing in a relatively short time, indications on the activity of a large variety of compounds. The present study aims to highlight and quantify the cytotoxic effect of the chemical components in the structure of removable prosthesis restorative materials, following their contact, washing and elution by saliva (in our experimental case by a substitute thereof, artificial saliva).

\section{Experimental part}

A number of 5 preparations were included in the cytotoxicity testing circuit, coded as follows: SA - (artificial saliva, incubation environment of various dental materials); SA - Titan (ionically diffused in artificial saliva); SA - Verasoft (ionic diffused in artificial saliva); SA - Superpont (ionic diffused in artificial saliva); SA - Nitinol (ionic diffused in artificial saliva). Artificial saliva has a chemical composition and $\mathrm{pH}$ similar to natural saliva, mimetic medium being a solubilizing or mobilizing agent of some ions from the composition of the dental restoration materials with which it is in direct contact. The biological material used in the in vitro test experiments of the cytotoxic impact of the eluates was represented bynormal, non-contaminated kidney cell cultures (obtained from the monkey kidneys of Cercopithecus aethiops), maintained in $25 \mathrm{~cm}^{2}$ plates. These plates contain DMEM growth medium (Dulbeco's Modified Essential Medium, Biochrom AG, Germany) supplemented with $2 \%$ fetal bovine serum, $100 \mu \mathrm{g} / \mathrm{mL}$ streptomycin (Biochrom AG, Germany), $100 \mathrm{IU} / \mathrm{mL}$ penicillin (Biochrom AG, Germany) and $50 \mu \mathrm{g} / \mathrm{mL}$ amphotericin $B$ (Biochrom AG, Germany), being placed in an incubator with a humidified atmosphere, $5 \% \mathrm{CO}_{2}$, and a temperature of $370^{\circ} \mathrm{C}$ [1-3]. When the cell cultures reached the monolayer stage, achieved by the confluence of the RM cells, they were detached from the lower solid substrate of the plate using a $0.25 \%$ trypsin solution and $0.02 \%$ EDTA (ethylene diamine tetra acetic acid, Biochrom AG, Germany), then centrifuged at $1800 \mathrm{rpm}$ for $2 \mathrm{~min}$ and suspended one more in normal medium. Volumes of $2 \mathrm{~mL}$ of cell suspension, with a density of $1 \times 105$ cells / mL, were inoculated into the test tubes, which were maintained, at different time intervals, under the same environmental conditions, in the incubator [4-6]. $24 \mathrm{~h}$ after the start of the experiment, when the monolayer phase of the daughter cultures was performed, the growth medium in the test tubes was decanted and replaced either with a normal one (in the case of control cultures) or with one containing liquid samples to be tested in volume. $0.2 \mathrm{~mL} / \mathrm{mL}$ culture medium (in the case of treated cultures) $[2,4,5]$. After another in vitro development interval, which provides $48 \mathrm{~h}$ cell treatment, 72-hour-old cultures were removed for growth medium, and the cell layer was washed with TFS (phosphate buffered saline), and then subjected to different methods for biochemical determination of total protein content by the Lowry method modified by Oyama. The values of total protein content, expressed in $\mu \mathrm{g}$ protein / culture and recorded in the control and treated cultures were inserted in the tables and converted into another index of evaluation of the cytotoxic impact of the various biological preparations, this being the degree of development of the cell cultures represented graphically. Its disturbance represents the realization of their impact on protein synthesis inhibitors, mito-inhibitors, disruption on apoptosis and cell viability $[5,6]$. In order to obtain direct indications regarding the interaction of the agents investigated with the process of cell mitosis, with apoptosis and cell viability, we developed a new experimental model compatible with their evaluation during the evolution of the different cell culture variants of RM, in which the modern flow cytometry technique was used. Thus, after $24 \mathrm{~h}$ from the formation of the initial cell cultures, the 25 $\mathrm{cm}^{2}$ culture vials were separated into the two experimental variants, one for tracking the cell proliferation process and the other for investigating apoptosis and cell viability [5-6].

Investigation of the cytotoxic effect of the samples included in the in vitro screening on normal animal eukaryotic cell cultures required: estimation of the total protein concentration at 72 hours of the control, reference and treated cultures for 48 hours; establishing the impact of the studied biological preparations on the cell proliferation process and appreciating the amplitude of their mito-

\footnotetext{
*email:cisaveanu@prevod.umfiasi.ro; daniulia05@yahoo.com,Phone:+40745 701535
} 
inhibitory effect; evaluation of the consequences of exposure of normal kidney cell cultures to the action of ionic eluates on cell viability; evaluation of the degree of cell apoptosis, all these evaluation indices reflecting and actually conditioning the direct interaction of the agents with the monkey kidney cells and their degree of development. There were used for each category of monkey kidney cell culture and five culture tubes, this being the minimum number required for statistical calculation using Student's t test and histograms.

\section{Results and discussions}

In a series of two successive tests, the events of the protein synthesis of the monkey kidney cells were expressed, expressed by the concentration of the total cellular proteins, during the $48 \mathrm{~h}$ evolution of the cultures in the growth medium containing adequate volumes of ionic, solubilized and drained eluates. Arficial saliva from the fragments of some incubated dental materials. The average values of the index of evaluation of the reactivity of the cellular protein synthesis, are inserted in table 1 and graphically represented in figure 1 . In the following, we will present the results of our investigations on the in vitro reactivity of monkey kidney cells, by the action of samples from Titanium, Nitinol, Verasoft (Cr-Ni), Superpont, biochemically characterized as ionic diffusers, obtained from different dental materials in artificial incubation saliva. Their presentation in histogram 1 is performed in the order of the intensity of the observed cellular protein synthesis.

\section{Table 1}

PROTEIN CONCENTRATION ( $\mu$ G PROTEIN / CULTURE) OF $72 \mathrm{~h}$ OLD MRI CELL CULTURES, IN THE CONDITIONS OF THEIR GROWTH DURING THE LAST $48 \mathrm{~h}$ IN THE PRESENCE OF IONIC DIFFUSERS ( $0.5 \mathrm{~mL} / 1 \mathrm{~mL}$ CULTURE MEDIUM) FROM DIFFERENT DENTAL MATERIAL

\begin{tabular}{|c|c|c|}
\hline Crop variant & X \pm ES & P \\
\hline WITNESS & $281.22 \pm 6.38(5)$ & - \\
SA & $213.40 \pm 3.86(5)$ & $<0.001$ \\
\hline SA - Titan & $202.87 \pm 2.94(5)$ & $<0.001$ \\
\hline SA - NiTi & $182.80 \pm 4.08(5)$ & $<0.001$ \\
\hline SA - Verasoft & $179.42 \pm 2.84(5)$ & $<0.001$ \\
\hline SA - Superpont & $177.40 \pm 13.61(5)$ & $<0.001$ \\
\hline
\end{tabular}

As can be seen, for each material tested, 5 samples from the ion diffuser were used to obtain conclusive results (number in parentheses). The percentage values of cell development and developmental inhibition in relation to cell culture control and saliva control, appear differentiated according to the ionic eluates mobilized by the saliva in the material, at the set time interval (fig.1). From the histogram and the above table, it can be observed that the evolution of the cultures of control monkey kidney cells is characterized, at $72 \mathrm{~h}$ interval, by average values of the total protein concentration; by their progressive growth, it argues for the intensification of cellular protein synthesis, correlated (as we will see in the results obtained under the investigation of the cell proliferation process) with the increase of the number of cells, by amplifying the rate of cell multiplication, the factors inherently imprinting the normal development of the control cultures. The incubation

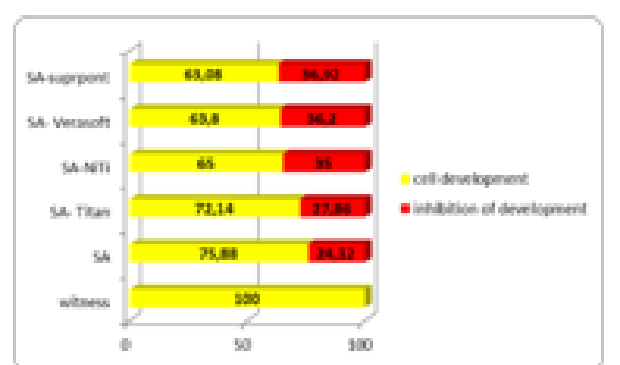

Fig. 1. Alteration of the process of development of the cultures of monkey kidney cells, expressed by the decrease of the intensity of the cellular protein synthesis

of the RM cell cultures with the artificial saliva led to the recording of average values of the protein concentration, which reveals a different behavior of the cell cultures upon its action.

Thus, compared to the control, the 72-hour-old reference cell cultures (48 of which were treated with artificial saliva) are characterized by a statistically significantly reduced average protein content, the impact of proteinsynthesorbate disturbance being the cause of an inhibition of the development of the RM cultures that reach a level of $24.12 \%$. [2,7] In the case of the mobilized ion samples from Titan we notice moderate, statistically significant changes in the intracellular protein contents, compared to the control concentration, the disruptive effect on the cellular protein biosynthesis being potentiated (this time compared to the reference cultures treated only with artificial saliva) by $3.74 \%$ by Titan ions. The presence, in the culture medium of the monkey kidney cells, of the ionic eluates resulting from the incubation of the dental materials of NiTi, Verasoft, Superpont, causes a reduction of the degree of cell development, compared to the control group, with values between 34.12 and $40 \%$. Excluding the influence of artificial saliva, the carrier of the different ions released from the structure of the dental materials used, the degree of inhibition of cell development only by the dental materials was: $10.88 \%$ (NiTi), $12.08 \%$ (Verasoft), $12.80 \%$ (Superpont). The comparative analysis of the intensity of the cellular protein synthesis, compared to the control cultures, but especially to the reference cultures, allows a firsthierarchy (in descending order) of the dental materials from the point of view of the cytotoxic potential: Titan, NiTi, Verasoft, Superpont.

Another aspect pursued in the investigation of the cytotoxic influence of the different dental materials for dental use was the reactivity of the process of proliferation of normal monkey renal cells to the action of the different ionic eluates of some dental materials in artificial saliva by flow cytometry. Compared with point 0 , that of cell culture initiation, we find in the control group a decrease of the fluorescence intensity, which signals a normal division process. The decrease of this fluorescence is not very great, which can be explained by the fact that, using normal cells, without alteration of the control of cell proliferation, the cell division diminishes as a rate when the monolayer phase is reached, a natural consequence of the functioning of the contactinhibition. The group treated with artificial saliva (SA) has a profile similar to that of the control group, which shows an unaltered evolution by the presence of this transporting agent in the culture medium of normal cells RM. A minimal effect on the cell proliferation process of normal monkey kidney cell cultures was found also in the case of normal monkey kidney cell cultures treated with SA-Titan, SA-Verasoft, the registered profile overlapping with that registered in the control group or the reference one (artificial saliva). Slight changes in the proliferative profile 

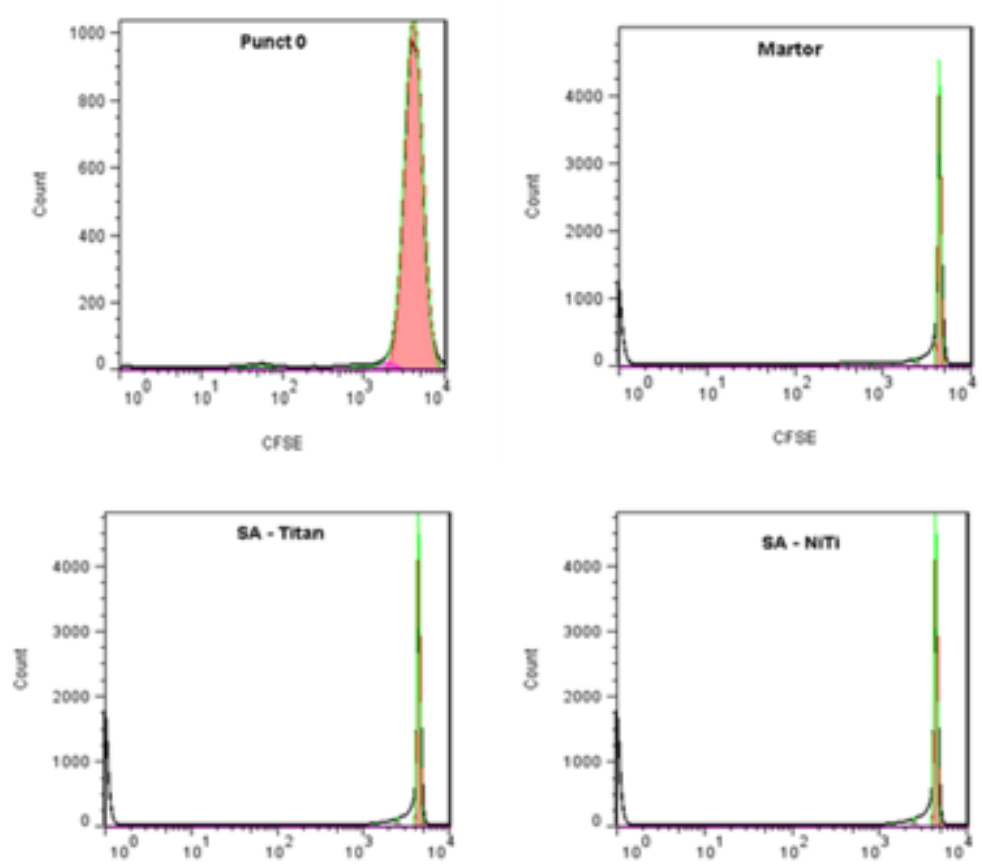

CFBE
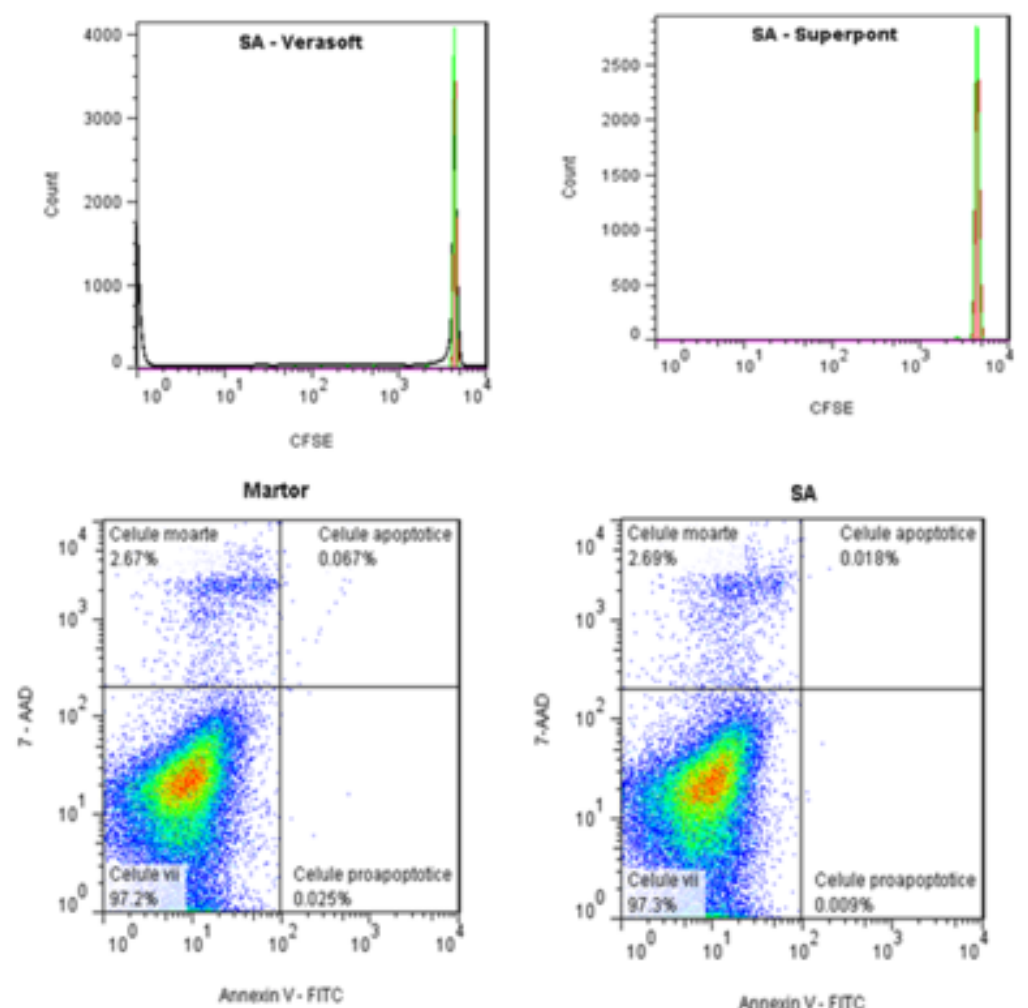

Fig. 2. Cell proliferation process of monkey kidney cell cultures, recorded in continuous cell flow at the Beckman Cell Lab Quanta SC blue laser (488nm) ot monkey kidney cell cultures treated with the tested dental materials are found in SA-Superpont. However, these deviations (the magnitude of which does not exceed significant values) from the specific profile of the control and the reference group can be based on normal physiological variations that occurred during the cell proliferation process (fig. 2).

Flow cytometry analysis of cell viability and apoptosis in monkey kidney cell cultures, raised under normal environmental conditions, underlined a very good viability of control cells, argued by the high percentage of living cells $(97.2 \%)$ and the presence of a percentage very low for dead cells (2.67\%), recommending the experimental use of this cell line. At the same time, we find that the population of component cells of the control cultures comprises a negligible number of pre-apoptotic $(0.014 \%)$ and apoptotic $(0.035 \%)$ cells, which confer the necessary quality of experimental biological material to our RM cultures. Incubation of RM cultures in the growth environment, voluntarily contaminated with artificial saliva, led to the appreciation of an increased viability of cell cultures - expressed by the very high proportion of living cells $(97.7 \%)$ and extremely small of dead cells $(2.28 \%)$. This relation between living and dying cells, in contrast to the behavior of cellular protein synthesis in a similar situation, attests the physiologically inert, therefore nontoxic, of artificial saliva and thus its quality of vector suitable for ions mobilized from various dental materials (fig. 3).

A similar behavior to the control and the reference characterizes the RM cell cultures treated with artificial saliva containing Titanium ions, mobilized from this dental material can be seen in figure 4 . The viability and cell apoptosis are almost identical to those of the control and reference cultures. And in this case, we are witnessing a 

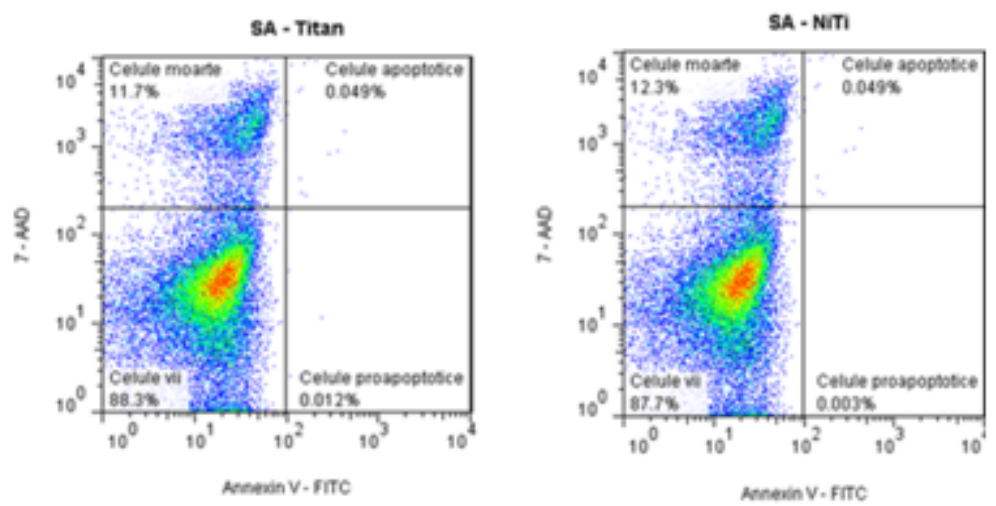

ig. 4. Flow cytometric analysis of cell viability and apoptosis in monkey kidney cell cultures grown under ambient conditions contaminated with SA-Titan ionic eluates

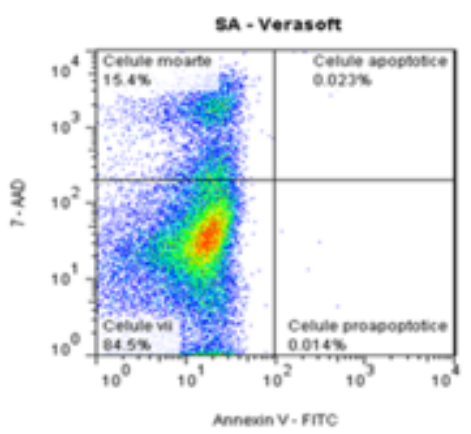

value difference between the cytotoxic potential of Titanium ions, estimated by the biochemical test of protein synthesis (10.88\% through the reactivity of the process to artificial saliva) and the one recorded by continuous flow cytometry (almost zero, so very well tolerated by cells). The difference found is not large in size, so we can afford to appreciate that Titanium-based dental materials are well tolerated by monkey kidney cell cultures (probably those of the oral cavity organs, digestive tract and other viscera, where the Titanium ions can reach after their transport by the liquids of the internal environment) the cellular processes of protein synthesis, apoptosis and those that imprint the cell viability being affected to a small and insignificant extent.

If the ions of the dental materials (Titanium), tested by artificial saliva, can be labeled as agents with reduced cytotoxicity, both on the basis of biochemical and flow cytometry results, it seems that the samples made by incubating the pieces from Verasoft and Superpont in the same solubilizing agent, mobilizer and vehicle, artificial saliva, appear to act as agents with aggressive action on cells (fig. 5).

In the case of these materials the very low percentages of living cells ( 14.7 and $17.6 \%$ respectively) are observed, but also the very high percentage values of dead cells (85.3\%, respectively $82.4 \%)$, by the near disappearance complete cases of pre-apoptotic cells and by increasing, as a subunit, the number of apoptotic cells $(0.042 \%$ and $0.052 \%$ respectively); these quantitative estimates were made after only 48 hours contact of the biological material with Verasoft samples, and Superpont and with a modern method of high accuracy, sensitivity and precision. We can say that monitoring the in vitro behavior of some cellular processes and their consequences (protein synthesis, apoptosis, cell viability) is appropriate for the study of the toxicity of some dental materials and allows their classification in terms of the likely cytotoxic potential: dental materials with negligible experimental cytotoxic action on monkey kidney cells (Titanium Verasoft and Nitinol) and therefore with very good biocompatibility, without side effects, side effects; dental materials with a major cytotoxic potential, possibly generating significant adverse reactions (Verasoft and Superpont samples). Also, in additional Nitinol alloy, one of the most used today in modern orthodontics, Andraeson introduced NiTi wires for orthodontic treatment. The composition of the wire used in orthodontics is $55 \%$ Nickel and $45 \%$ Titanium and the first company to market Nickel-Titanium springs was $3 \mathrm{M}$ Unitek. The introduction of this type of alloy has revolutionized the field of orthodontics, due to the light continuous forces that allow for more wide and complex range of dental movements compared to those obtained with stainless steel springs. Over the years the manufacture and composition of NiTi springs has improved so that they have low rigidity, super elasticity, high strength, and high elastic range. The NiTi wires have excellent spring-back and deliver the lightest force. However, these wires are expensive, have poor formability, and cannot be soldered or welded and have high arch wire-bracket friction. The wires with least load/deflection have highest super elasticity and can thermal or stress induced. Thermoelasticity is due to temperature induced austenite to martensitic transformation while stress induced martensitic transformation is by applying force. [8-11] . Every time will be different between laboratory aspects and clinical aspects. concerning tisular reactions [12]. These aspects were also demonstrated in others studies [13-22]. It is difficult to explain, at this moment, the difference noticed between the two mentioned aspects, it being probably related to the differentsensitivity of the two methods of investigation, biochemical and flowcitometric. Due to the non-synchronization of the experimental data, an uncertainty is installed in the assessment of the real cytotoxic potential of the dental materials, the biochemical test of the evaluation of the protein synthesis appearing to be less accurate than the continuous cell flow cytometry.

\section{Conclusions}

Within the limits of this study we can conclude that the Titanium and Nitinol materials exhibit an experimental cytotoxic action on very small monkey kidney cells and thus a very good biocompatibility and the materials Verasoft and Superpont have a major possible cytotoxic potential that generates notable adverse reactions. 


\section{References}

1.ABBRO L., LANUBILE R. , DINI L. Recent. Res. Devel. Cell Sci, $2004 ; 1: 83-97$.

2.CANN A.J., (2002), Maths from scratch for biologists, John Wiley $\&$ Sons Ltd, 83-146.

3.DOYLE A., GRIFFITHS J.B., John Wiley \& Sons Ltd, West Sussex , 1998

4.GATIN E., PIRVU D., CARA R.R. Digest J ournal of Nanomaterials and Biostructures 2011, 6 (3):1333-1342

5.MACEY, M. G. Flow cytometry: principles and applications. Humana Press Totowa, New Jersey, 2007.

6.ROBINSON J. P., DARZYNKIEWICZ Z., HOFFMAN R., NOLAN J., ORFAO A., RABINOVITCH P., WATKINS S. John Wiley \& Sons, Inc., 2003

7.SABALIAUSKAS V, JUCIUTE R, BUKELSKIENE V, RUTKUNAS V, TRUMPAITE-VANAGIENE R, PURIENE A. Stomatologija. 2011;13(3):7580.

8. MIURA, F.; MOGI, M.; OHURA, Y.; HAMANAKA, H. Am J of Orthod and Dentofacial Orthopedics.1986;90 (1): 1-10

9.HIGA RH., CASTANHA J F., JANSON HG., MATIAS M., SALVATORE DE FREITAS K.M, PINELLI F., FÁVARO H M. (2017), Progress in Orthodontics 2017;18(21):1-7.

10. ARREGHINI A, LOMBARDO L, MOLLICA F, SICILIANI G. Int Orthod. 201614(1):1-14.
11.GATTO E., MATARESE G. , DI BELLA G., CHIARA BORSELLINO R.C. AND CORDASCO G., European J ournal of Orthodontics 2013;35: 115-123.

12.GIUROIU CL; CARUNTU ID; LOZNEANU L; et al. BIOMED RESEARCH INTERNATIONAL 2015 Article Number: 960321

13.VIERIU, R.M., TANCULESCU, O., MOCANU, F., et al., Mat. Plast., 52, no. 2, 2015, p. 266-271

14.IOVAN, G., STOLERIU S., PANCU,G., etal., Mat. Plast., 54, no. 2,2017, p. $375-379$

15.IOANID, N. IFTENI, G. GRADINARU, l.; et al.ROMANIAN JOURNAL OF ORAL REHABILITATION 2016;8(2): 09-114

16.SOLOMON, S.M; TANCULESCU, 0.; SCUTARIU, M.M; et al. INTERNATIONAL JOURNAL OF MEDICAL DENTISTRY 2017;21(4) 290293 Published: 2017

17.SOLOMON, S.M.; STOLERIU, S.; TIMPU, D.; et al. Mat.Plast,,53, no. 4, 2016, p. 796-798

18. WANG L, HOFFMAN RA. Curr Protoc Cytom. 2017 J an 5; 79:1.3.11.3.27.

19. CARLSON ED, GAN R, HODGMAN CE, JEWETT MC. Bioethanol Adv. 2012 30(5):1185-94

20.GUAN X, CHAFFEY PK, ZENG C, TAN Z. Top Curr Chem. 2015;363:15592

21. IWASAKI S., INGOLIA N.T. Trends in Biochemical Sciences., mai, 2017

22.ADAN A., ALIZADA G, KIRAZ Y, BARAN Y\& NALBANT A. Crit Rev Biotechnol, Early Online: 2016: 1-14

Manuscript received: 18.06 .2019 